\title{
Evaluation and Treatment of Nasal Obstruction Developed after Rhinoplasty
}

\author{
Jong Sook Yi and Hong Ryul Jin \\ Doctor Jin's Premium Nose Clinic, Seoul, Korea
}

코성형 후 발생한 코막힘의 평가와 치료

이 종 숙·진 홍 률

닥터진이비인후과

Received May 28, 2018 Accepted June 12, 2018 Address for correspondence Hong Ryul Jin, MD, PhD Doctor Jin's Premium Nose Clinic, 621 Gangnam-daero, Seocho-gu, Seoul 06524, Korea

Tel $+82-2-2088-8585$

Fax +82-2-2088-6543

E-maildoctorjin@daum.net
Nasal airway obstruction is one of the most frequent causes of revision rhinoplasty despite the golden rule that nasal function should not be sacrificed because of cosmetic reason. Nasal function is jeopardized due to diverse reasons including inaccurate diagnosis or inadequate surgical technique. Detailed and thorough evaluation of the nose with review of previous operative technique is necessary to find out exact causes of obstruction. Septum, middle vault, tip, nostril, and nasal mucosa are common anatomic areas of obstruction after rhinoplasty. They are often weakened, damaged, or even destroyed losing their original shape, strength, or position. Changes in these anatomic structures are strongly related to static and/or dynamic obstruction. In this article, authors reviewed the common locations, anatomic causes, and treatment strategies of nasal obstruction after rhinoplasty.

Korean J Otorhinolaryngol-Head Neck Surg 2018;61(8):387-95

Key Words Deformed nose · Nasal obstruction · Revision rhinoplasty · Revision septorhinoplasty.

\section{서 론}

코성형에서 중요한 사항 중의 하나는 미용적인 면을 위해 기능을 희생하면 안 된다는 점이지만 불행히도 5 20\%에 달 하는 환자들이 코성형 후에 코막힘을 호소한다. ${ }^{1-11)}$ 원활한 비강 호흡은 정상적인 생활을 영위하기 위한 필수 조건으로 이것이 충족되지 않는다면 미용적으로 아무리 만족한다 하 여도 그 수술은 실패한 것이다.

코성형 후의 코막힘의 원인은 너무나 다양하며 복합적이 므로 이를 해결하기 위한 수술법 또한 일정한 패턴을 찾기는 어렵다. 많은 코성형 논문이 있지만 코성형 후 발생한 코막힘 에 대한 연구는 많지 않아 본 논문에서는 코성형 후 코막힘이

This is an Open Access article distributed under the terms of the Creative Common Attribution Non-Commercial License (https://creativecommons.org/licenses/by-nc/4.0) which permits unrestricted non-commercial use, distribution, and reproduction in any medium, provided the original work is properly cited.
발생할 경우 흔한 코막힘의 발생 부위와 이에 기여하는 해부 학적인 원인, 그리고 원인에 따른 수술법을 정리하고자 한다.

\section{환자의 평가}

코성형 후에 코막힘으로 온 환자를 평가할 때 제일 중요한 점은 막히는 부위가 어디이며 그 해부학적 원인이 무엇인가 하는 것을 파악하는 것이다. 이 두 가지를 정확하게 평가하여 야 비로소 어떻게 문제를 해결할 것인가를 결정할 수가 있다.

코성형을 한 환자에서 막히는 부위를 파악하는 것은 쉽지 가 않다. 본인이 수술한 환자가 아니라면 환자의 수술 전 코 의 상태를 정확히 파악하기가 힘들고, 절제나 이식 등으로 인 해 코의 구조물의 변화가 있고, 조직 또한 이전 수술로 인해 정상적이지 않기 때문이다. 원래 조금씩 있던 코막힘이 악화 된 것인지 아니면 전혀 없던 코막힘이 새로 발생한 것인지도 
알아야 하며, 수술 전부터 알레르기나 비중격만곡 등이 있었 는지도 파악하여야 한다. ${ }^{3,12,13)}$

먼저 코안에서는 비중격을 자세히 살펴보아야 한다. 미측 비중격(caudal septum)이 휜 경우는 전비경 검사로 쉽게 파악 할 수 있으며 비첨이나 비공의 비대칭이 동반되는 경우도 흔 하다. 비중격의 후방이 휜 경우는 비강의 점막을 축소시키고 내시경으로 살펴보는 것이 도움이 된다. 하비갑개의 비후나 과도한 절제 여부, 비중격 점막의 비후도 점막 축소 전후로 잘 살펴보아야 한다. 또한 비중격 천공, 비내 유착의 여부도 같이 살펴보아야 한다. 외비의 모양에서도 코막힘의 부위를 파악하 는 단서를 얻을 수가 있다. 예를 들어 inverted v deformity 등이 보일 경우 상외측연골이 내측, 아래측으로 전위된 것을 알 수가 있다(Fig. 1). ${ }^{14)}$ 환자의 문진상 이전 수술에서 절골술 을 시행했거나 매부리를 제거했다면 내비밸브 부위에서 막힐 가능성은 높아진다. 측면에서 보아 middle vault가 꺼진 안장 코는 어떤 이유이든 비중격의 지지가 소실되어 상외측연골이 나 하외측연골이 여러 방향으로 변화가 온 것을 시사한다. ${ }^{15)}$ 외비가 휘어진 경우 비중격의 변형이 동반되어 있을 가능성 이 높기 때문에 비중격을 자세히 살펴보아야 한다. ${ }^{8,16)}$ 코를 정 면에서 보았을 때 상비익구(supra-alar groove)가 깊어 괄호 처럼 보이는 '찝힌 코'의 경우는 하외측연골 외측각의 변형, 혹은 결손이 있어 비익이 비강측으로 함몰되어 보이는 것이 다(Fig. 2). ${ }^{16,17)}$ 이는 외비밸브가 좁아져 코막힘이 잘 발생한 다는 것을 의미한다. 외측각이 작고 약한 경우 과도하게 돔간 봉합(interdomal suture)을 시행하거나 비주지지 혹은 비중격 연장술에 외측각을 과도하게 내측으로 모을 경우 외측각이 내측으로 끌려오면서 비강측으로 함몰되는 경우에 흔히 이

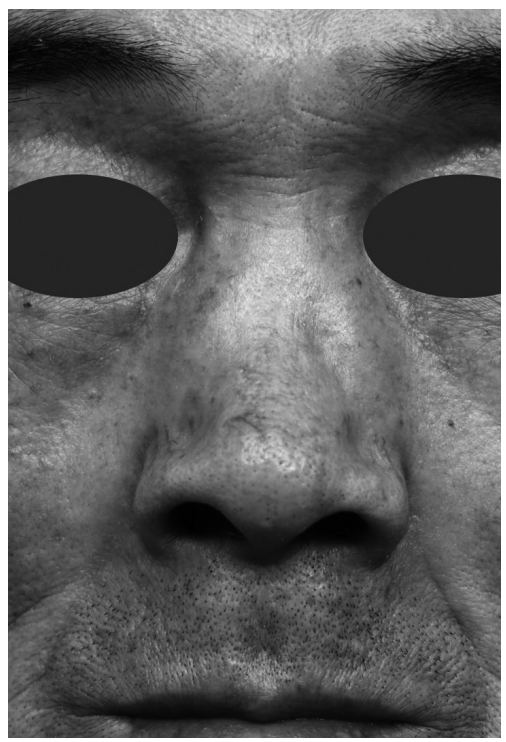

Fig. 1. Separation of the upper lateral cartilages from the nasal bone leads to an 'inverted- $V$ deformity.'
러한 현상이 발생한다. 비공의 모양, 비전정부의 협착, 비저의 절제 여부와 흔히 절개 부위의 반흔 형성, 피부 손상 등으로 비공 협착이 없는지도 살펴보아야 한다.

코막힘은 특정 부위가 좁아져 공기의 흐름과 상관없이 늘 막히는 정적(static)인 것이 가장 흔하지만 공기의 흐름이 증가 될 때만 코막힘이 발생하는 동적(dynamic) 코막힘도 발생할 수 있다. 과도한 외측각의 절제 혹은 여러 번의 수술로 인해 상, 하 외측연골이 약해지면 비외측벽의 동적인 허탈이 쉽게 발생한다. 이때 점막수축, modified cottle test, cottle test가 코막힘의 개선 여부에 도움이 되는지를 평가해 보아야 한다.

주관적인 코막힘의 평가는 NOSE scale로 비교적 정량화 할 수가 있다. 이 외에도 visual analogue scale도 도움이 된 다. ${ }^{16)}$ Acoustic rhinometry, rhinomanometry 등은 코막힘 부위나 정도를 기계적으로 정량화하여 측정하는 데 도움이 된다. ${ }^{18)}$ 내시경을 이용한 코 안의 촬영은 비중격만곡, 비내 유 착, 비중격천공, 알레르기, 하비갑개 이상, 내비밸브의 협착 여부 등을 시각적으로 파악하는 데 도움을 준다. 반면 CT는 concha bullosa 등 코 안의 구조 이상, 축농증 등을 파악하는 데 도움을 주며 특히 절골술로 인해 비강이 좁아진 경우, 양 측 비골의 길이 차이가 현저한 경우, 심한 비중격만곡증이 있 는 경우, 비중격천공 등이 있을 때 객관적인 정보를 제공한다.

코성형 후에 코막힘이 발생한 환자분들은 많은 경우에서 미용적인 불만 또한 가지고 있으므로 재수술에서 이 점을 어 떻게 해결할 것인지도 미리 생각하여야 한다. 대부분 기능적 인 문제를 해결하면서 미용적인 향상도 이룰 수가 있지만 반 드시 그렇지 못한 경우도 발생한다. 예를 들어 환자분은 얇 고 날씬한 콧대를 원하지만 기능적 필요에 의해 비골을 외측

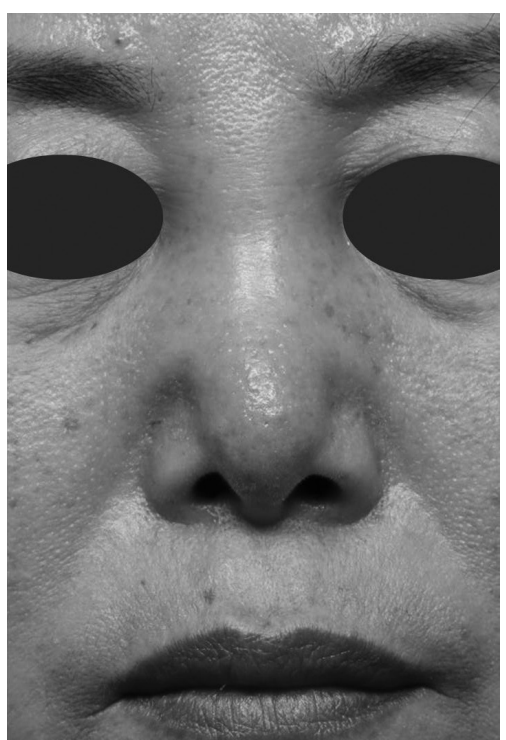

Fig. 2. Deformed lateral crus of lower lateral cartilages lead to pinched nose appearance. 
으로 옮기거나 펼침이식 혹은 나비이식 등을 시행할 경우 비 배의 폭이 조금 증가되기 때문에 이 점은 환자와 수술 전에 긴밀히 상담하여야 한다. ${ }^{19,20)}$

\section{코막힘이 발생하는 부위와 그 원인}

코성형술 후에 코가 막혀 재수술이 필요한 환자들을 분석하 여 보면 그 원인을 몇 가지 부류로 나눌 수가 있다(Table 1). ${ }^{16)}$

첫째, 비중격의 문제이다. 기존의 비중격만곡증을 제대로 교정하지 못했거나 교정을 하다가 더 심해진 경우도 있고, 아 무 문제가 없던 비중격인데 연골 채취, 비중격연장술 등의 조 작을 하다가 비중격이 휘는 경우도 있다. 수술 전에 있던 비 중격만곡증이 제대로 교정 안된 이유는 연골-골 접합부를 충분히 분리하지 못하여 비배쪽의 휜 비중격(high septal deviation)이 제대로 교정 안된 경우가 가장 흔하다. 이는 keystone의 손상을 너무 우려하여 연골을 골에서 충분히 분 리되지 못하여 연골이 휘어진 채로 남기 때문에 발생한다. 특 히 비중격연골 자체의 만곡이 있을 경우 이를 cross hatching 등으로 교정을 시도하다가 오히려 만곡이 심해지거나 반대측 으로 휘는 경우도 볼 수 있다. 미측비중격이 휘는 경우도 흔 한데 최근 비첨성형술을 위해 비중격연장술을 하다 미측비 중격이 휘어지는 경우가 많아지고 있다. 간혹 비중격이 큰 문
제가 없었음에도 불구하고 비중격 연골을 채취하고 콧등에 실리콘 등을 이식한 후 미측비중격의 만곡이 심해진 경우도 볼 수가 있는데 이는 L-strut, 특히 caudal L-strut을 충분히 남기지 않은 상태에서 실리콘의 압력으로 약한 비중격 연골 이 휘기 때문이다. 또한 비중격만곡증 수술 이후 발생한 비 중격천공도 정상적인 공기의 흐름을 방해하는 와류가 발생 하여 코가 막히는 원인이 된다.

둘째, middle vault의 문제이다. 내비밸브는 코성형 후에 흔 히 좁아지기 쉬운데 대표적인 경우가 매부리코를 절제한 이 후에 keystone 부위를 제대로 재건하지 못한 경우이다. 매부 리코의 비혹은 비중격연골, 상외측연골, 비골의 세 부분으로 이루어지는데 이 부위를 절제하면 상외측연골이 비골에 붙 은 부위가 떨어지면서 내측, 아래측으로 이동하여 비강이 좁 아지게 되고 겉으로 보면 상외측연골이 비골연에서 떨어져 소위 말하는 'inverted v deformity’를 만들게 된다. 또한 외 측절골술을 해서 과다하게 비골 피라미드를 좁히면 여기에 붙은 상외측연골이 내측으로 이동하면서 비밸브가 좁아져 코막힘을 호소한다. 여러 번의 코성형술로 상외측연골을 포 함한 비배가 상흔(scar tissue)으로 덮이고 구축이 오면서 연 골의 손상이 발생하는 경우도 볼 수가 있다. 상외측연골이 많 이 손상되어 비강이나 비배에서 보면 멀쩡해 보여도 실제로 는 상외측연골은 흐물흐물하고 비강 내측으로 이동하여 내

Table 1. Factors for evaluation of patients who developed nasal obstruction after rhinoplasty

\begin{tabular}{|c|c|c|c|}
\hline Location & Type & Anatomic cause & Surgical correction \\
\hline Septum & Static & $\begin{array}{l}\text { Uncorrected/new deviation } \\
\text { Caudal/dorsal deformity } \\
\text { Septal perforation }\end{array}$ & $\begin{array}{l}\text { Deviation correction } \\
\text { Reconstruction/replace } \\
\text { Perforation repair }\end{array}$ \\
\hline Middle vault & Static & $\begin{array}{l}\text { ULC collapse after aggressive hump } \\
\text { resection/lateral osteotomy } \\
\text { Damaged ULC }\end{array}$ & $\begin{array}{l}\text { Spreader graft } \\
\text { Flaring suture } \\
\text { Lateralizing osteotomy } \\
\text { Butterfly graft }\end{array}$ \\
\hline Tip/lateral crus & $\begin{array}{l}\text { Dynamic or } \\
\text { static }\end{array}$ & $\begin{array}{l}\text { Congenital } \\
\text { Overresection } \\
\text { Paradoxical concavity }\end{array}$ & $\begin{array}{l}\text { Lateral crural strut } \\
\text { Alar batten graft } \\
\text { Flip flop technique }\end{array}$ \\
\hline $\begin{array}{l}\text { External valve } \\
\text { (nostril) }\end{array}$ & Static & $\begin{array}{l}\text { Cicatrical stenosis } \\
\text { Overresection of alar base } \\
\text { Thick, overgrafted columella } \\
\text { Deviated columella } \\
\text { Tip ptosis }\end{array}$ & $\begin{array}{l}\text { Scar excision, Z-plasty, Composite graft } \\
\text { External epithelial flap } \\
\text { Graft removal or thinning } \\
\text { Support of tip }\end{array}$ \\
\hline Dorsal collapse & Static & $\begin{array}{l}\text { Loss of septal support } \\
\text { Nasal bone depression } \\
\text { Tip ptosis }\end{array}$ & $\begin{array}{l}\text { Reconstruction of L-strut } \\
\text { Nasal bone repositioning } \\
\text { Support of tip }\end{array}$ \\
\hline Mucosal lining & Static & $\begin{array}{l}\text { Mucosal hypertrophy/loss } \\
\text { Adhesion }\end{array}$ & $\begin{array}{l}\text { Medical therapy } \\
\text { Pedicled flap } \\
\text { Adehesiolysis }\end{array}$ \\
\hline
\end{tabular}

ULC: upper lateral cartilage 
비밸브를 포함한 외측벽이 약해지면서 비강이 좁아져 코막 힘이 유발된다.

셋째, 하외측연골의 손상을 포함한 비첨의 이상이 있으면 코막힘이 발생한다. 비첨을 수술하면서 하외측연골을 너무 내측으로 당겨오면 외측각이 내측 하방으로 당겨지면서 비전 정내로 연골이 튀어나와 콧구멍이 좁아져 코가 막히게 된다. 또한 외측각을 과다하게 절제하거나 손상을 시키면 비익연골 부분이 함몰되거나 흡입시에 비강내로 함몰되는 동적허탈 (dynamic collapse) 현상이 발생하여 코막힘을 유발한다.

넷째, 비공을 포함한 외비밸브의 문제이다. 비교적 흔한 문 제 중의 하나는 반복된 수술로 인한 조직의 손상으로 비공의 협착(cicatrical stenosis)이 온 경우이며 교정이 쉽지가 않다. 짧은 기간 동안 반복적으로 여러 번 수술한 경우, 감염으로 인해 코끝 피부가 일부 괴사되거나 상처를 입은 경우, 무리하 게 코끝을 연장하거나 높일 경우 코끝 피부가 손상을 입으면 서 협착이 진행되는 경우가 흔하다. 절개한 부위를 제대로 봉합하지 못하거나 절개를 잘못 넣어 조직이 상한 경우에도 콧구멍이 좁아지는 경우도 있다(Fig. 3). 심한 경우는 콧구멍 전체가 전부 좁아지면서 숨을 쉬기가 힘들어지는 경우도 발

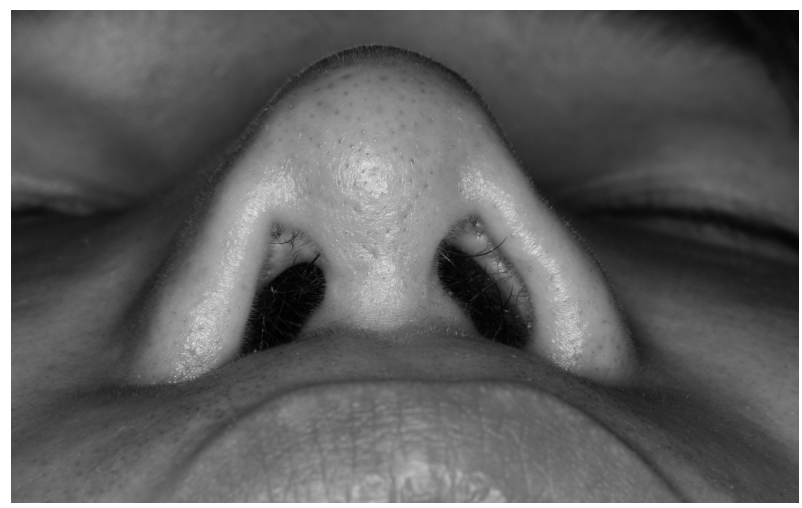

Fig. 3. Nostril stenosis developed by scar contracture around the previous incision area.

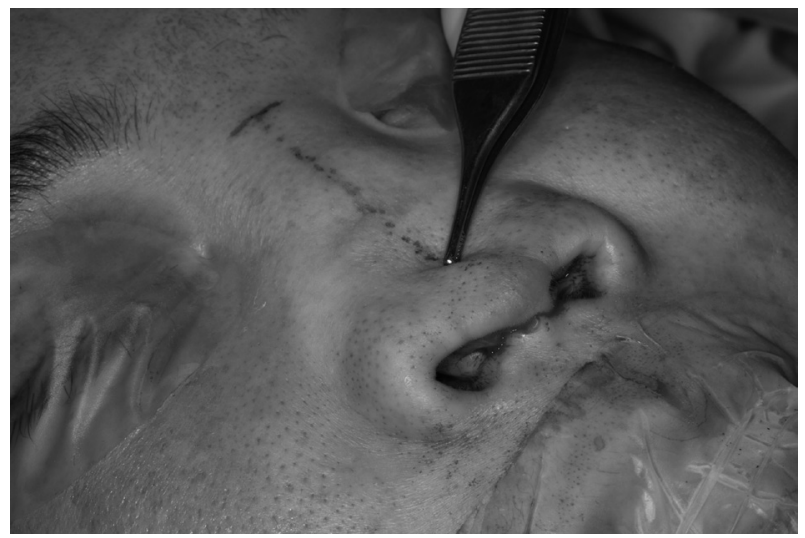

Fig. 4. Nasal dorsal collapse developed by total structural loss of the septum.
생한다. 뿐만 아니라 비익연의 절제를 과다하게 해서 콧구멍 이 수술 전보다 많이 좁아져 코막힘을 호소하는 경우도 있고 이로써 좁아진 비공과 미측비중격의 만곡이 동반되어 일측 코막힘을 호소하는 경우도 있다. 또한 코끝이 아래로 처지고 비주의 높이가 낮아진 경우 외비밸브가 좁아져 코로 숨 쉬는 것이 원할하지 않게 된다.

다섯째, 전체 비배의 함몰이 발생하면서 코가 막히는 경우 다(Fig. 4). 반복된 수술로 비중격의 지지가 완전히 소실된 경 우 주로 발생하지만 외상, 웨게너씨육아종(Wegener's granulomatosis), 코카인중독 등의 질병으로도 발생한다. 과도한 절골술로 비골의 함몰이 발생하는 경우도 있을 수 있다. 비 배가 함몰되면 상외측연골이 같이 내려앉으면서 비강이 좁아 지며 흔히 같이 동반되는 비중격의 변형으로 인해 코가 더 막 히게 된다.

여섯째, 비강내 점막의 문제이다. 하비갑개의 비후 혹은 치 료하지 않은 알레르기 등이 있을 수가 있다. 수술을 고려하 기 전에 항상 약물로 최대한 치료를 시도해 보고 수술 여부 를 결정하여야 한다. 과도하게 하비갑개를 절제하여 코가 건 조하고 오히려 코가 더 막히는 경우도 발생할 수 있다. 비강 내의 점막 소실 혹은 비전정 부위 피부의 손상으로 유착, 협 착이 온 경우도 있다.

\section{수술적 치료}

\section{비중격의 교정}

코성형 후 발생한 비중격의 만곡의 교정은 흔히 양측 점막 의 박리와 함께 비외접근법으로 전체 비중격을 조망하는 것 이 필요하다. 후방 비중격은 똑바르고 미측비중격만 휜 경우 에는 굳이 전체 비중격을 박리할 필요는 없지만 추가적인 연 골 채취나 배측비중격(dorsal septum)의 교정이 필요한 경우 가 많아 필요한 만큼 충분히 박리하여야 제대로 비중격을 교 정할 수가 있다.

기존의 비중격만곡이 제대로 교정되지 않은 경우 골-연골 접합부를 충분히 분리하지 않았거나 뒤쪽의 휜 사골수직판 을 충분히 제거하지 못한 것을 흔히 볼 수 있다. 이는 keystone 부위의 손상을 너무 우려하여 충분히 분리하지 않았거나 좁 은 시야에서 수술하여 접합부의 위, 아래를 전부 보지 못해서 발생하는 현상이다. 따라서 이 경우에는 충분히 연골을 골과 분리하고 휜 부분을 절제해 주어야 하고 그다음 나머지 휜 연 골에 대한 교정을 시행하여야 한다.

미측비중격의 만곡이 남아있을 때 교정하는 대표적인 방법 은 splinting(batten) graft, curvature cut and realignment, caudal septal replacement 등이 있다. Splinting graft는 연골 
Fig. 5. Caudal septal curvature cut and realignment. Preoperative photo shows C-shape curved caudal septum while it is still attached to anterior nasal spine (A). Most convex site was cut and realigned with batten graft (B).
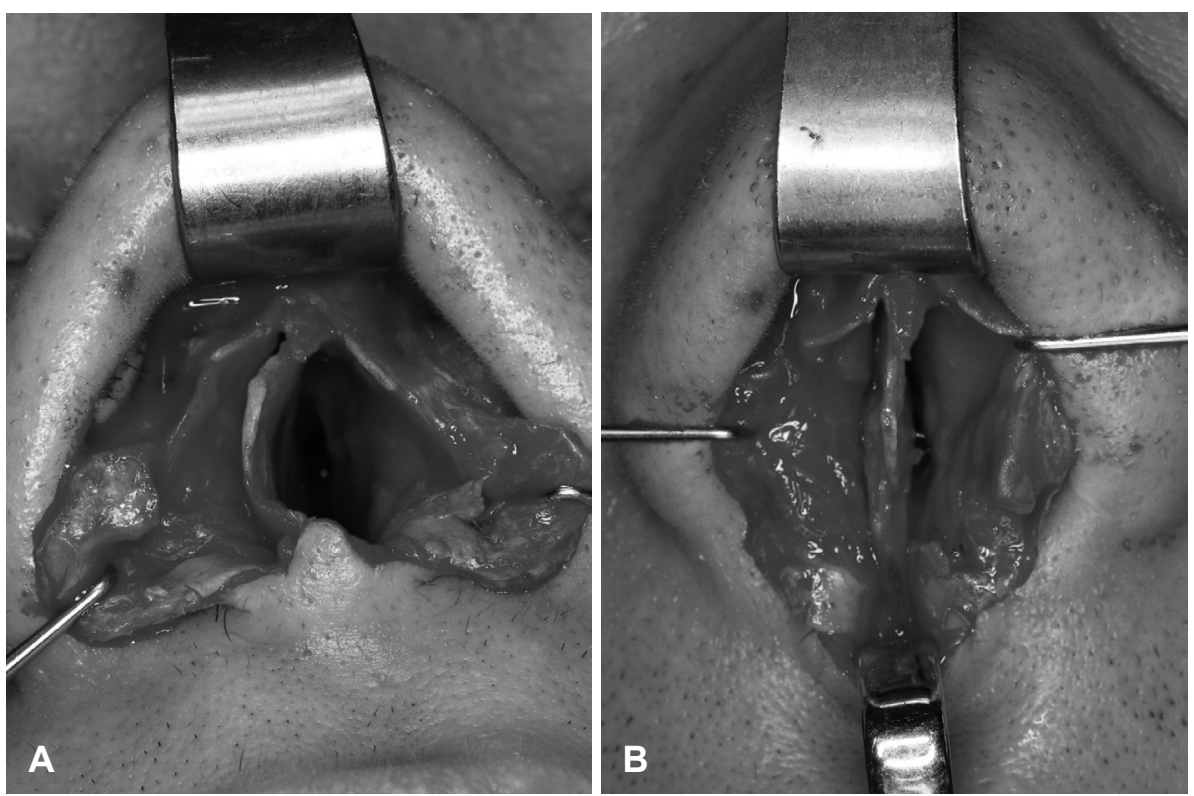

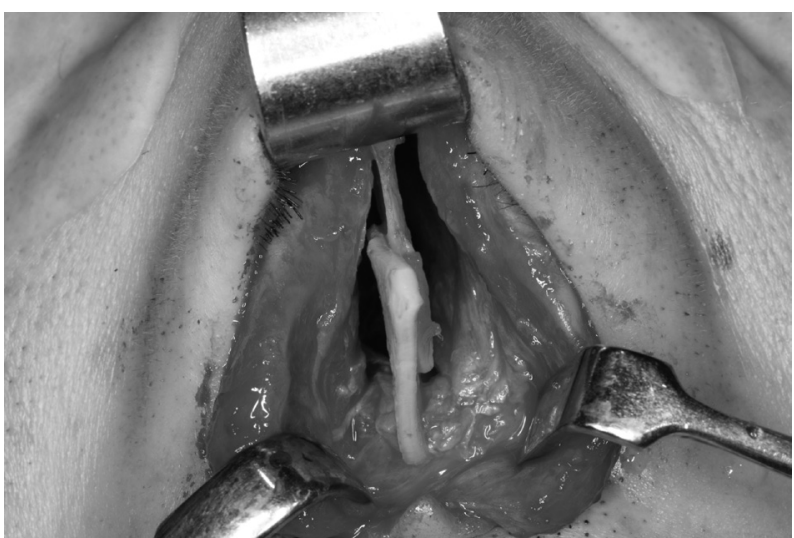

Fig. 6. Caudal septal replacement was done in sagittal midline with firm fixation to the anterior nasal spine.

로 하는 것이 제일 좋으나 재료가 부족하면 아주 얇은 비중격 뼈 혹은 흡수성 플레이트를 이용할 수도 있다. 뼈를 이용할 때 주의할 점은 너무 두꺼우면 안되고 비중격의 범위를 넘어 뼈를 이식하는 것은 코 전체가 딱딱하게 될 수 있어 피해야 한 다. 간혹 무리하게 splinting만으로 만곡을 교정하려 하다 보 면 만곡이 제대로 교정되지 않는 경우가 발생하는데 이 경우 에는 휘어져 있는 연골을 충분히 칼집을 넣어(releasing incision) 약화시킨 다음 splinting을 하는 것이 좋다.

Curvature cut and realignment는 미측비중격의 휜 정도가 아주 심하지 않고 전비극 접합부에서 비중격이 휘거나 이탈 되지 않은 경우에 효과적이다(Fig. 5A). 가장 만곡이 심한 부 분에 절개를 넣어 dorsal strut과 caudal strut을 분리한 다음 위치를 다시 재조정하여 비중격이 똑바로 되는 지점, 그리고 dorsal height이 유지되는 지점을 찾아 서로 봉합하거나 아니
면 splinting graft와 같이 봉합하게 된다(Fig. 5B).

Caudal septal replacement는 미측 비중격의 손상이나 변 형이 심하고 너무 약화된 경우에 이를 반듯하고 힘이 있는 연 골로 대체해주는 것을 말하는데 주로 뒤쪽에 남아있는 비중 격연골이나 늑연골이 많이 이용된다. 대체할 때 중요한 점은 시상면(sagittal plane)에서 midline을 잡고 전비극에 연골을 확실하게 고정하여 축이 흔들리지 않도록 해주어야 한다는 점이다(Fig. 6).

미측비중격의 만곡 말고도 배측비중격(dorsal septum)의 만곡이 남아 있는 경우도 많다. 이 경우에는 배측비중격과 상 외측연골을 분리하여 먼저 휜 비중격을 교정해야 한다. 가벼 운 만곡은 요면에 칼집을 넣은 다음 펼침이식(spreader graft) 으로 교정하고 조금 더 휜 경우는 뼈를 이용한 splinting을 하 기도 한다. 심한 만곡은 curvature cut and realignment 한 다 음 splinting을 추가로 대주는 교정이 필요하다.

비중격손상이 너무 심해 그 자체로 교정이나 재건이 불가 능한 경우는 부분 혹은 전체 비중격 치환술이 필요하며, 특히 $\mathrm{L}-$ strut의 복원이 필요하다. 코뼈에 구멍을 뚫거나 골막을 이 용하여 재건한 비중격을 keystone 부위와 전비극에서 확실 히 고정해 주어야 비중격이 안정되고 안비가 발생하지 않는다. 그다음 상외측연골을 이 비중격에 다시 부착하여 준다.

\section{비밸브 넓히기, 비측벽 강화}

비밸브와 비측벽의 약화를 수술하는 방법은 대표적인 것으 로 펼침이식(spreader graft), 비익강화이식(alar batten graft), 나비이식(butterfly graft), flaring stitch 등을 들 수 있다.

이 중 펼침이식은 약화된 middle vault를 강화 시키면서 내 
비밸브를 넓혀주는 역할을 한다. 펼침이식은 배측비중격의 길이만큼 길고 적절한 두께와 함께 3 4 mm 정도의 높이가 필요하다(Fig. 7). 너무 길게 하거나 너무 짧아도, 혹은 너무 두껍거나 얇아도 좋지 않다. 대개 양측으로 한 겹 정도로 이 식하지만 필요에 따라서는 두 겹, 세 겹의 이식을 하기도 한 다. 이식편을 먼저 비중격에 고정한 다음 상외측연골을 다시 부착하게 된다. 재부착 할 때 상외측연골이 좌우 대칭이 되도 록 주의해야 하며 상측 분리연에서 너무 아래쪽으로 봉합하 여 오히려 상외측연골이 내측으로 이동하면서 코막힘이 발생 하지 않도록 유의하여야 한다. 오히려 약간의 flaring이 일어 나게 비배연(dorsal edge) 쪽으로 봉합하는 것이 기능적인 면 에서 더 유리하다.

비익강화이식(alar batten graft)은 상외측연골의 미측, 혹은 하외측연골의 두측 부위, 즉 내비밸브와 외비밸브의 사이(intervalve area)의 비측벽이 약화되면서 내측, 비강측으로 함몰 되는 것을 방지하는 수술법이다. 비중격연골, 혹은 귀연골을 사 용하며, 길이가 충분하여 pyriform aperture 부위까지 걸쳐지게 해야 비측벽이 함몰되는 것을 방지할 수가 있다(Fig. 8)(Supplementary Video 1 in the online-only Data Supplement).

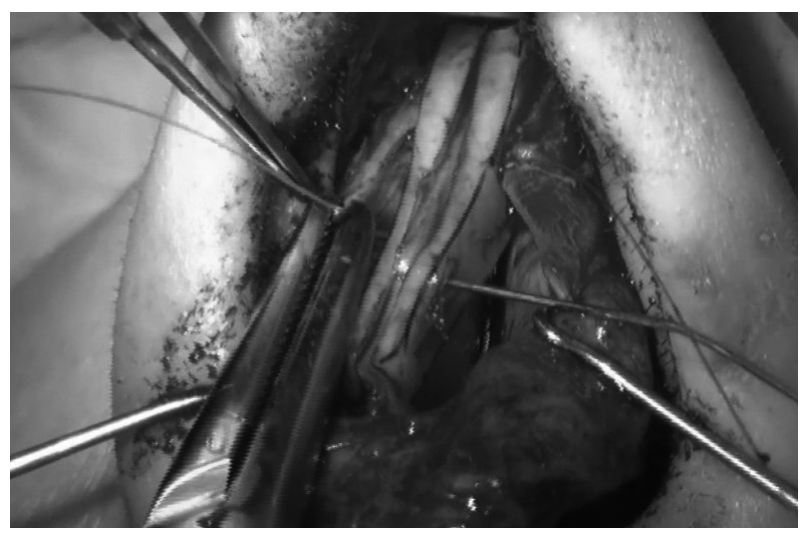

Fig. 7. Spreader graft should ideally have the same length as dorsal septum with an appropriate thickness and height.
나비이식은 귀연골의 탄성을 이용하여 비측벽이 내측으로 함몰되는 것을 방지해주는 역할을 한다. 귀연골의 두께가 있 기 때문에 상비첨 부위의 비배가 펑퍼짐해 보이거나 매끄럽지 못할 수 있으므로 시행 시 주의해야 하며 상외측연골을 귀연 골에 잘 봉합하여 flaring 잘되도록 하는 것이 중요하다(Fig. 9). 앞서 언급한대로 이 술식은 middle vault를 약간 들어 올 리는 효과로 인해 코가 약간 두꺼워 보이기 때문에 수술 전에 이점에 대하여 환자와 충분히 상의하고 동의를 구하는 것이 중요하다.

Flaring stitch는 배측비중격을 중심으로 상외측연골이 위 로 벌어지도록 봉합하는 것을 말한다(Fig. 10). 이는 비중격 이 잘 지지가 되고 상외측연골이 어느 정도의 강도를 가지고 있을 때 유용하다. 만약 상외측연골이 많이 손상되어 봉합으 로 벌어지지 않을 경우는 이 부위를 연골 이식을 통하여 보강

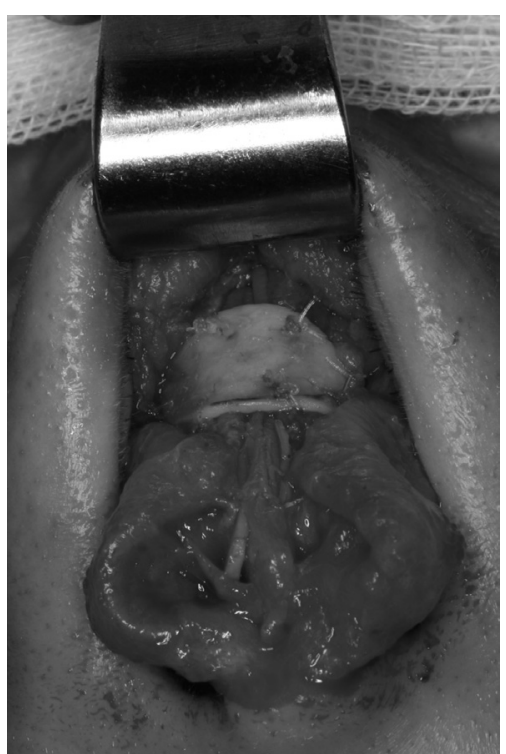

Fig. 9. Butterfly graft carved from conchal cartilage was applied to the dorsum.
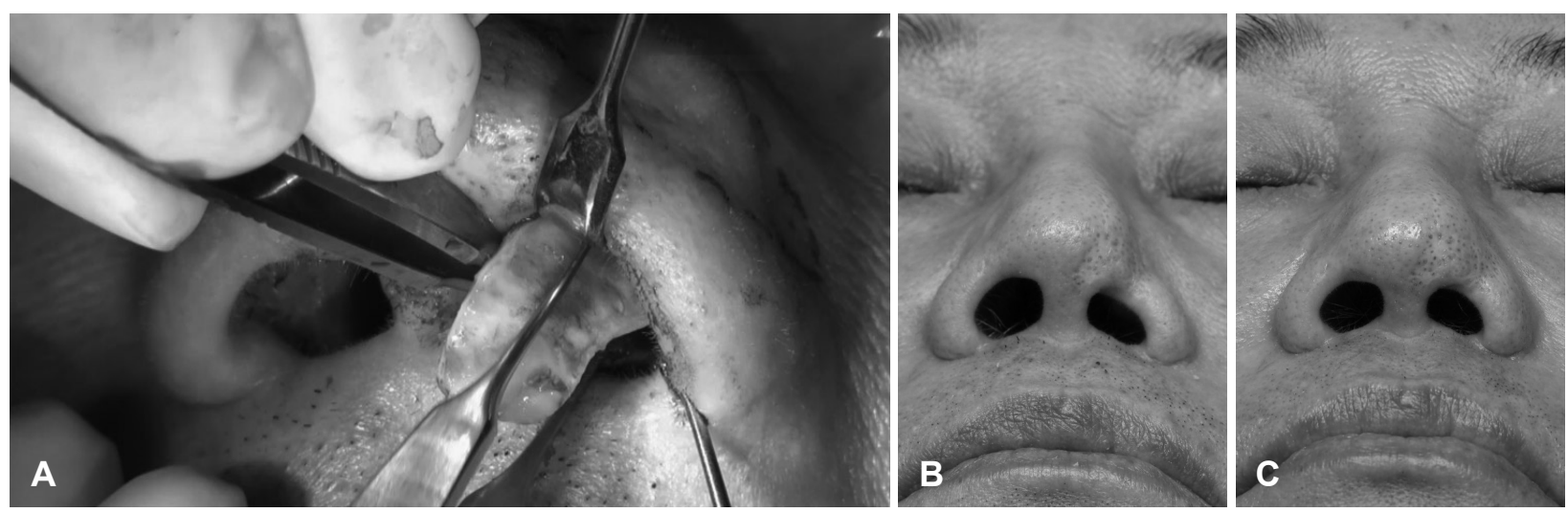

Fig. 8. Alar batten graft can improve lateral nasal wall collapse developed after trauma. The graft should be long enough to cover from midline to pyriform aperture (A). Preoperative photo (B). Postoperative photo (C). 


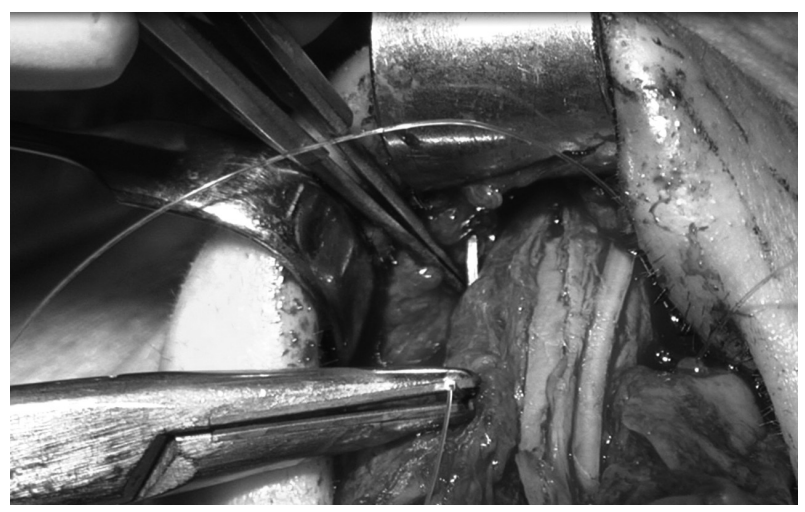

Fig. 10. Flaring suture can widen the nasal valve area by pulling the upper lateral cartilage upward. It can be applied alone or in combination with spreader graft.

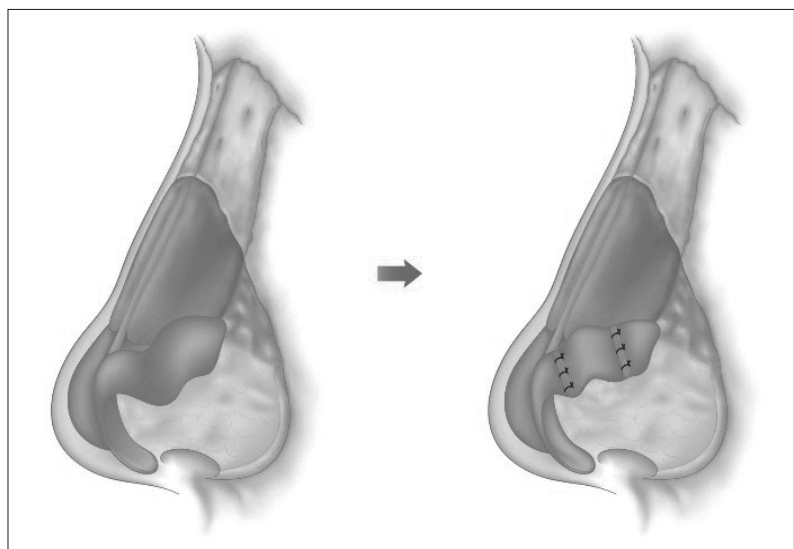

Fig. 11. Flip-flop technique to correct paradoxically concave lateral crus.

하여 주어야 한다. 흔히 여러 번 수술을 받은 환자의 경우에 서 상외측연골의 미측이 많이 손상된 것을 볼 수가 있으며 이 는 결국 내비밸브가 좁아지는 현상을 초래하거나 흡입할 때 내측벽이 코 안으로 말려 들어가는 동적허탈(dynamic collapse)을 유발한다.

\section{비첨의 문제 해결하기}

하외측연골의 외측각이 비강측으로 오목하게 돌출된 경우 는 외측각보강이식(lateral crural strut graft)이나 외측각을 뒤 집어 붙이는 flip-flop technique으로 교정한다(Fig. 11). 하 외측연골이 과도하게 절제되거나 여러 번의 수술로 손상이 된 경우에는 비중격연골이나 귀연골로 하외측연골을 재건한 다. 외측각보강이식은 손상된 외측각의 아래쪽에 보강이식 을 하는 것으로 외측각을 지지하여 비공으로 함몰되는 것을 방지하여 정적, 동적 코막힘을 해결할 수가 있다.

\section{외비밸브, 비공 넓히기}

좁아진 비공이 미측비중격 혹은 비주의 과다한 연골이식
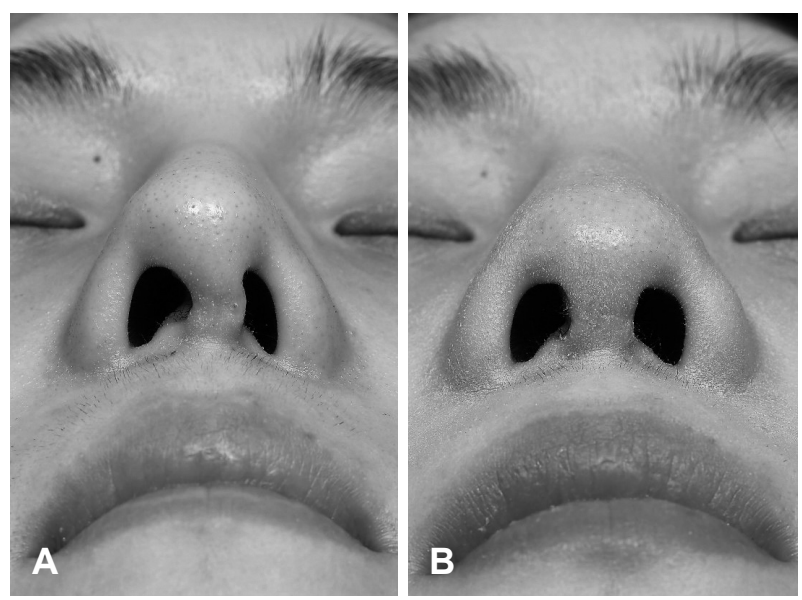

Fig. 12. Deviated columellar correction. Columella is deviated obstructing the left nostril (A). Deformed medial crus was strengthened and made straight, improving the nostril shape (B).

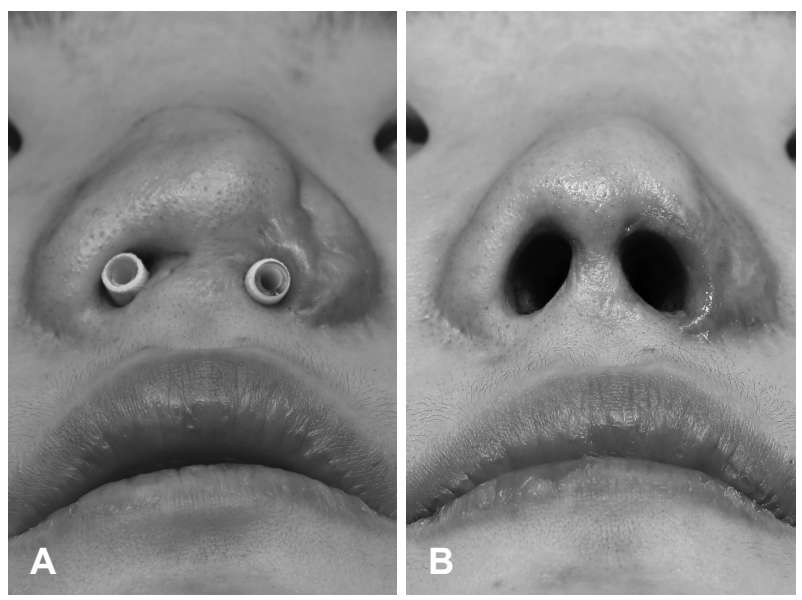

Fig. 13. A patient with nostril stenosis. The patient could only breath through the tube inserted into the nostril (A). Nostril stenosis was improved after scar tissue removal and ear cartilage composite graft transplantation (B).

등으로 생긴 것이면 비교적 교정은 쉽다. 과다하게 이식된 연 골은 제거하고 날렵한 이식물로 바꾼 다음 떠 있는 피부, 점막 은 봉합한다. 실리콘 등의 이물질로 전상악부위를 이식했던 경우 감염이 발생하면서 동반된 부종이 비공을 막는 경우도 있으며, 영구 필러 등의 이물질이 비전정 부위를 막아 코막힘 을 유발하기도 한다. 이러한 경우 이물질을 제거하고 염증을 치료하면 저절로 좋아진다. 드물게 비주를 구성하는 하외측 연골의 내측각이 많이 손상되면서 비주가 틀어져 한쪽 비공 이 막히는 경우가 있을 수 있다(Fig. 12A). 손상된 내측각을 복원하여 비주를 중심에 유지하는 것이 코막힘을 해소하는 방법이다(Fig. 12B).

상흔으로 협착된 비공을 넓히는 것은 쉬운 일이 아니다 (Fig. 13A). 상흔 조직이 많아 비공을 둘러싸면서 좁아진 경우 에는 상흔을 제거하고 비공과 비전정 피부를 z-plasty로 넓혀 
주거나 피부가 모자란 경우에는 이개연골복합이식(conchal composite graft) 등으로 이식하면 어느 정도의 확장은 가능하 다(Fig. 13B). 하지만 아주 오랫동안 비공확장기(nostril retain$\mathrm{er}$ )를 사용하여야 하며 최종적으로는 수술 직후의 크기보다 많이 좁아지게 된다.

비주, 비익, 비저 등의 피부가 많이 손상된 경우에는 이러한 방법만으로는 좋은 결과를 얻기가 불가능하다. 상흔 제거 후 에 결손이 큰 경우에는 피부 피판술이 필요하다. Interpolated melolabial flap이 대표적인 예이며 비강점막, 지지연골, 피부 등의 세 층을 전부 복원하여야 한다.

\section{비배함몰의 치료}

코막힘이 동반되지 않은 가벼운 함몰인 경우에는 비중격을 손대지 않고 연골이식 등을 통하여 모양만을 교정하면 된다. 하지만 코막힘이 동반된 경우 코의 함몰은 비중격의 지지가 없어지면서 상외측연골이 같이 낮아지면서 비밸브가 좁아져 코가 막히는 것이기 때문에 이를 같이 해결해 주어야 한다. 먼저 비중격의 높이와 지지를 복원하고 여기에 맞추어 상외 측연골을 다시 배치시켜 좁아진 비강을 열어주어야 한다. 비 중격지지를 복원함과 미용적 목적을 위해 비배의 이식도 필 요한 경우가 많으며 이 경우 상외측연골을 비배이식물에 고정 하면서 위쪽으로 들어주는 봉합(flaring suture)이 매우 중요 하다. 함몰이 심하면 코끝의 지지가 소실되면서 코끝이 떨어 져 코가 막히는 경우도 있으므로 코끝의 높이도 같이 복원하 는 것이 필요하다. 많은 환자에서 이전의 수술로 남아있는 비 중격이 없어 늑연골을 써야 하는 경우가 많다.

\section{점막비후 및 손실의 치료}

감염이나 비중격 만곡으로 인한 비강 점막, 하비갑개의 비 후 등도 코막힘을 유발할 수가 있다. 일단은 약물로 조절해 보고 실패할 경우 고주파를 이용하거나 점막하절제술로 하 비갑개의 비후를 조절해주어야 한다. 전신적인 염증질환, 예 를 들어 웨게너씨육아종(Wegener's granulomatosis) 등은 비 중격을 포함하여 코의 지지구조 소실과 함께 비강점막의 파 괴를 유발하기도 한다. 전신 염증을 잘 조절한 후에 수술하 면 좋은 결과를 얻을 수도 있다.

비강 점막의 소실은 비강내의 남아있는 정상 조직의 피판 술을 이용하여 재건할 수가 있다. 예를 들어 하비갑개 점막 의 외측을 기저로 하여 비첨, 비중격 부위의 결손을 재건할 수 있으며, 비중격피판은 비첨부 비강내 결손을 재건할 수 있 지만 두 피판 모두 추가적인 피판 분리가 필요하다.

\section{결 론}

코성형술 후에 발생하는 코막힘은 다양한 부위에서 복합 된 양상으로 발생하기 때문에 어느 부분이 막히는지, 그 해 부학적 원인은 무엇인지를 파악하는 것이 치료에 가장 중요 하다. 여러 가지 기능적 개선을 도모하는 코성형 술기 등을 막히는 부위와 그 원인에 따라 적절히 적용하면 코성형술 후 에 발생한 코막힘을 해결하는 데 많은 도움을 준다.

\section{Supplementary Video Legend}

Supplementary video 1 . which demonstrates endonasal alar batten graft, is available in the online-only data supplement.

\section{REFERENCES}

1) Lee M, Zwiebel S, Guyuron B. Frequency of the preoperative flaws and commonly required maneuvers to correct them: a guide to reducing the revision rhinoplasty rate. Plast Reconstr Surg 2013;132(4):769-76.

2) Bussi M, Palonta F, Toma S. Grafting in revision rhinoplasty. Acta Otorhinolaryngol Ital 2013;33(3):183-9.

3) Yu K, Kim A, Pearlman SJ. Functional and aesthetic concerns of patients seeking revision rhinoplasty. Arch Facial Plast Surg 2010; 12(5):291-7.

4) Adamson PA, Warner J, Becker D, Romo TJ 3rd, Toriumi DM. Revision rhinoplasty: panel discussion, controversies, and techniques. Facial Plast Surg Clin North Am 2014;22(1):57-96.

5) Becker DG, Becker SS. Reducing complications in rhinoplasty. Otolaryngol Clin North Am 2006;39(3):475-92.

6) Becker DG, Bloom J. Five techniques that I cannot live without in revision rhinoplasty. Facial Plast Surg 2008;24(3):358-64.

7) Fattahi T. Considerations in revision rhinoplasty: lessons learned. Oral Maxillofac Surg Clin North Am 2011;23(1):101-8.

8) Kamer FM, McQuown SA. Revision rhinoplasty. Analysis and treatment. Arch Otolaryngol Head Neck Surg 1988;114(3):257-66.

9) Pearlman SJ, Talei BA. An anatomic basis for revision rhinoplasty. Facial Plast Surg 2012;28(4):390-7.

10) Mazzola RF, Felisati G. Secondary rhinoplasty: analysis of the deformity and guidelines for management. Facial Plast Surg 1997; 13(3):163-77.

11) Waite PD. Avoiding revision rhinoplasty. Oral Maxillofac Surg Clin North Am 2011;23(1):93-100.

12) Sokoya M, Gonzalez JR, Winkler AA. Effect of allergic rhinitis on nasal obstruction outcomes after functional open septorhinoplasty. Am J Otolaryngol 2018;39(3):303-6.

13) Chambers KJ, Horstkotte KA, Shanley K, Lindsay RW. Evaluation of improvement in nasal obstruction following nasal valve correction in patients with a history of failed septoplasty. JAMA Facial Plast Surg 2015;17(5):347-50.

14) Atespare A, Boyaci $Z$. The use of spreader grafts in revision septoplasty. J Craniofac Surg 2016;27(7):1656-60.

15) Durbec M, Disant F. Saddle nose: classification and therapeutic management. Eur Ann Otorhinolaryngol Head Neck Dis 2014;131(2): 99-106.

16) Goudakos JK, Daskalakis D, Patel K. Revision rhinoplasty: retrospective chart review analysis of deformities and surgical maneuvers in patients with nasal airway obstruction-five years of experience. Facial Plast Surg 2017;33(3):334-8.

17) Kandathil CK, Spataro EA, Laimi K, Moubayed SP, Most SP, Saltychev M. Repair of the lateral nasal wall in nasal airway obstruction: a 
systematic review and meta-analysis. JAMA Facial Plast Surg 2018; 20(4):307-13.

18) Paul MA, Kamali P, Chen AD, Ibrahim AMS, Wu W, Becherer BE, et al. Assessment of functional rhinoplasty with spreader grafting using acoustic rhinomanometry and validated outcome measurements.
Plast Reconstr Surg Glob Open 2018;6(3):e1615.

19) André RF, Vuyk HD. The "butterfly graft" as a treatment for internal nasal valve incompetence. Plast Reconstr Surg 2008;122(2):73e-4e.

20) Clark JM, Cook TA. The 'butterfly' graft in functional secondary rhinoplasty. Laryngoscope 2002;112(11):1917-25.

\section{정답 및 해설}

답 (3)

해 설 Septoplasty 시행후에 발생한 septal hematoma (3) 비중격 혈종이 큰 경우에는 한쪽 점막 하부에 비강 저부와 평행하게 절개를 하거나 긴 반관통절개를 한 후 혈액과 혈괴 를 제거할 수 있으며, 이때 연골을 통한 양면 절개는 비중격 천공을 일으킬 수 있으므로 금기이다. 비중격 천공이 적절히 치료되지 않으면 안비와 같은 외비 기형, 섬유화에 따른 비중격의 비후와 비중격 농양, 비중격 천공 등을 초래하게 된다. 참고문헌: 이비인후과학-두경부외과학. 서울: 일조각;2009. p.1081-2. 